\title{
Awareness of the Dangers of High Salt Intake among the Urban Omani Population
}

Hassan Al-Riyami, ${ }^{1}$ Qusay Al-Abdulsalam, ${ }^{2}$ Ali Al-Khayari, ${ }^{2}$ Hilal Al-Mushrafi, ${ }^{2}$ Ziyad Al-Alawi, ${ }^{2}$ Khamis Al-Hashmi, "Sunil K. Nadar ${ }^{4}$

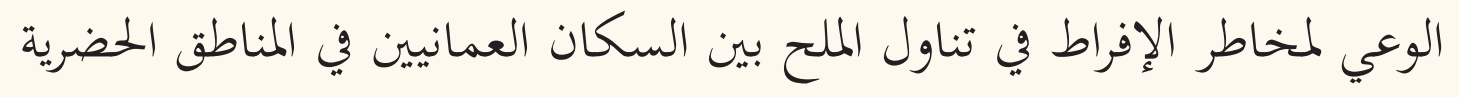

حسن الريامي، قصي العبد السلام، علي الخياري، هلال المشرفي، زياد العلوي، خميس الهاشمي، سونيل نادار

ABSTRACT: Objectives: This study aimed to assess the knowledge, attitudes and practices of the general public in Oman regarding the dangers of high salt intake. Methods: This cross-sectional questionnaire-based survey was conducted among the urban population in Oman. Individuals aged $\geq 18$ were invited to join the study. Results: A total of 1,214 respondents (mean age $34 \pm 10$ years) answered the questionnaire. The majority were male (65.8\%), employed (69.4\%) and some were hypertensive (14.3\%). Most (90.9\%) were aware that excess salt can cause diseases such as hypertension and that it is either somewhat important $(51.2 \%)$ or very important (42.9\%) to reduce salt in the diet. However, only $42.2 \%$ said that they actively try to reduce salt in their diet. Conclusion: Although most people in urban areas of Oman appear to be aware of the dangers of high salt intake, only a few are actively trying to reduce it. More educational activities are required to improve awareness.

Keywords: Cross-Sectional Survey; Sodium; Low Salt Diet; Oman.

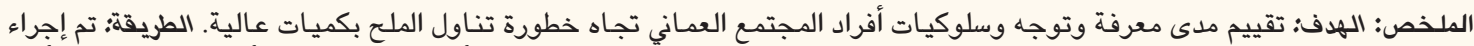

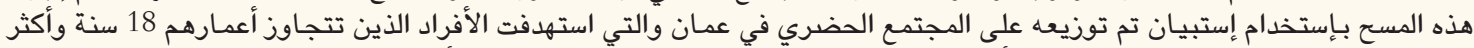

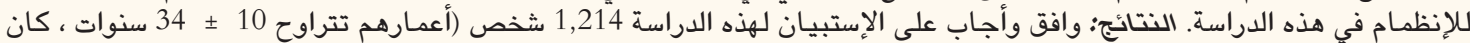

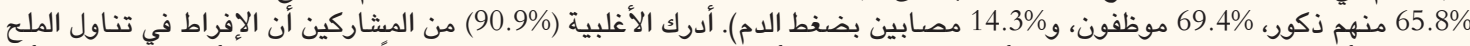

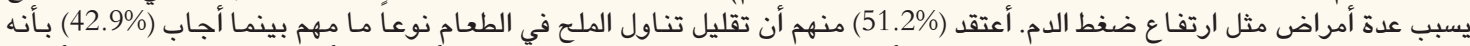

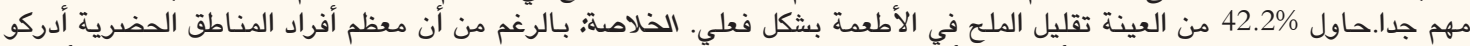

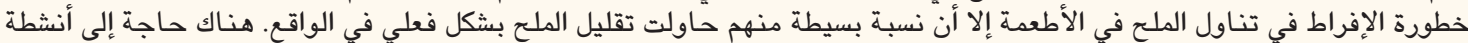

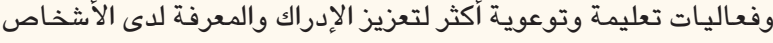
الكلمات المفتاحية: دراسة مقطعية؛ صوديم؛ طعام قليل الملوحة؛ عُمان.

$\mathrm{C}$ ardiovascular diseases (CVDs) are a leading cause of death and disability worldwide affecting more than 17.5 million people annually. ${ }^{1}$ Hypertension is a major risk factor of CVD and it is estimated that one in five deaths and 7\% of all disability can be attributed to suboptimal blood pressure control. ${ }^{2}$ High salt intake is a major risk factor for hypertension and is considered to be responsible for approximately one-third of hypertension or around 300 million people worldwide. ${ }^{3}$ In addition to hypertension, high salt intake is also found to be associated with Meniere's disease, osteoporosis and gastric and renal cell cancers. ${ }^{4-6}$ Modern Western diets which are high in processed foods tend to have a high salt content and is considered a major global health issue. ${ }^{7}$ In fact, the World Health Organization (WHO) has listed the reduction of dietary salt intake by $30 \%$ as one of its nine global targets to be achieved by the year $2025 .{ }^{8}$
As mentioned in the WHO recommendations, the ideal salt consumption by adults should be less than $5 \mathrm{~g}$ iodised salt/day. ${ }^{8}$ However, data from many countries have shown that the dietary intake of salt far exceeds this threshold. ${ }^{9}$ In accordance with these recommendations, many countries have undertaken measures to reduce salt in commercially processed foods and have also initiated measures to educate the general public and increase awareness about the harms of high salt intake and the need to reduce its consumption. ${ }^{10-12}$

In Oman, the prevalence of hypertension and CVD is high, with around $25 \%$ of the population being hypertensive and CVD accounting for around $42 \%$ of all deaths. ${ }^{13,14}$ The salt consumption in Oman is also high. According to the national nutrition survey published in 2004, the average salt intake in the Omani population was about $11-12$ g salt/day. ${ }^{15}$ The government has undertaken numerous measures to 
tackle the increasing prevalence of non-communicable diseases, including CVD, with the reduction of salt consumption being a particularly important area of interest. $^{13,16}$ Some of these measures include mass media campaigns and reduction of salt in locally produced bread. ${ }^{16,17}$

Despite these high-level campaigns, their impact on public awareness is not known. The aim of this study was to assess the knowledge and attitudes of the general public in an urban setting in Oman towards salt and whether this had any effect on their salt consumption. This may help us introduce new strategies to improve awareness and behaviour.

\section{Methods}

This cross-sectional questionnaire-based study was conducted among the general urban population in Muscat, Oman. The study was conducted from September to November 2019 and only adults aged $\geq 18$ years we included.

The subjects were recruited from various public areas in Muscat including parks and malls as well as student recreation areas of universities and colleges. In addition, the questionnaire was posted as a link on social media, specifically Whatsapp Messenger (Facebook ltd. Menlo park, California, USA), for further volunteer recruitment. No formal sample size calculations were possible as this was a cross-sectional study to assess the knowledge, attitudes and behaviour of the general public

The questionnaire was divided into two parts. The first part consisted of questions related to demographic characteristics of the participants such as age, educational and employment status and eating habits. The second part of the questionnaire collected data on their knowledge, attitudes and practices with regards to salt intake. This was based on a questionnaire devised by the WHO. ${ }^{18}$ The questionnaire was translated into Arabic by a native professional Arabic-speaker. It was then translated back into English to assess consistency. A pilot sample of 20 non-medical university students completed the questionnaire to eliminate or rephrase any questions that could cause confusion.

Sample size estimations were made according to recommendations for questionnaire-based studies, where a minimum of 384-400 participants were required for a standard error of $5 \%$ or a sample size of 1,000 participants for $3 \% .{ }^{19}$ This study opted for a minimum of 1,000 responses.

The data were analysed using Statistical Package Social Sciences (SPSS), Version 21 (IBM Corp., Armonk, New York, USA). All data are presented as either percentages or median (interquartile range). Mann-Whitney U test, Chi-square test and binary

logistic regression analysis were used for analysis. For the binary logistic regression, responses to the question "Do you do anything on a regular basis to reduce your salt intake?" were used as the outcome measure; all the demographic variables were used as the input variables. These factors were chosen as input variables as they are known to influence attitudes and behaviour. A $P$ value of $<0.05$ was considered statistically significant.

Ethical approval was granted by the Medical Research Ethics Committee, College of Medicine and Health Sciences at Sultan Qaboos University (MREC\#1579). There was a short paragraph before the questionnaire explaining the details of the study where the participants had to provide consent to participate. No personal identifiable data was collected.

\section{Results}

A total of 1,259 responses were received. However, 45 responses were excluded from the study due to incomplete questionnaires. The remaining 1,214 participants (403 paper responses and 811 electronic responses) were included in the study. The mean age of the participants was $34 \pm 10$ years with 799 (65.8\%) male and 173 (14.3\%) had hypertension. The majority of participants $(62.7 \%)$ had completed a diploma course or above while the remaining (37.3\%) had studied up to secondary school. Most of the respondents (69.4\%) were in active employment, while 47 (3.9\%) were students and 321 (26.4\%) were either retired or unemployed [Table 1]. All the respondents were from Muscat Governorate, Oman.

Table 1: Demographic characteristics of the participants from Muscat Governorate, Oman $(\mathrm{N}=1,214)$

$\begin{array}{lr}\text { Characteristics } & \mathbf{n}(\%)^{*} \\ \text { Age in years } & 34(27-40) \\ \text { Gender } & \\ \text { Male } & 799(65.8) \\ \text { Female } & 415(34.2) \\ \text { Education level } & \\ \text { Secondary school or below } & 453(37.3) \\ \text { Diploma or above } & 761(62.7) \\ \text { Occupation } & \\ \text { Employed } & 843(69.4) \\ \text { Student } & 47(3.9) \\ \text { Unemployed/Retired } & 321(26.4) \\ \text { Hypertensive } & 173(14.3) \\ \text { *The values are median (interquartile range) or number (\%). }\end{array}$


Table 2: Responses to the questionnaire about attitude, knowledge and practice of salt intake in a sample from Muscat Governorate, Oman $(\mathrm{N}=1,214)$

\begin{tabular}{|c|c|}
\hline Parameters & n (\%) \\
\hline \multicolumn{2}{|l|}{ Attitude toward salt intake } \\
\hline \multicolumn{2}{|c|}{ How important is lowering the salt/sodium in your diet? } \\
\hline Not at all important & $69(5.7)$ \\
\hline Somewhat important & $621(51.2)$ \\
\hline Very important & $521(42.9)$ \\
\hline \multicolumn{2}{|c|}{ Behaviour related to salt intake } \\
\hline \multicolumn{2}{|c|}{ Do you do anything on a regular basis to reduce your salt intake? } \\
\hline Yes & $512(42.2)$ \\
\hline No & $612(50.4)$ \\
\hline Don't know/not answered & $90(7.4)$ \\
\hline \multicolumn{2}{|c|}{ Do you add salt to food at the table? } \\
\hline Never/rarely & $481(39.6)$ \\
\hline Sometime & $362(29.8)$ \\
\hline Often/always & $345(28.4)$ \\
\hline Don't know/Not answered & $26(2.1)$ \\
\hline \multicolumn{2}{|c|}{ Do you add salt to food while cooking? } \\
\hline Never/rarely & $27(2.2)$ \\
\hline Sometimes & $158(13)$ \\
\hline Always & $974(80.2)$ \\
\hline Don't know/not answered & $57(4.7)$ \\
\hline \multicolumn{2}{|c|}{ Do you check the label before you buy any food for salt content? } \\
\hline Yes & $320(26.4)$ \\
\hline No & 894. (73.6) \\
\hline \multicolumn{2}{|c|}{ Knowledge related to salt intake } \\
\hline \multicolumn{2}{|c|}{$\begin{array}{l}\text { Do you think that a high salt diet could cause a serious health } \\
\text { problem? }\end{array}$} \\
\hline Yes & $1,103(90.9)$ \\
\hline No & $39(3.2)$ \\
\hline Don't know & $72(6.1)$ \\
\hline \multicolumn{2}{|c|}{ Can high salt in diet cause hypertension? } \\
\hline Yes & 964 (79.4) \\
\hline No & $9(0.7)$ \\
\hline Don't know & 241 (19.9) \\
\hline \multicolumn{2}{|c|}{$\begin{array}{l}\text { Do you know what the recommended maximum salt intake per } \\
\text { person per day is? }\end{array}$} \\
\hline Yes & $54(4.4)$ \\
\hline No & $1160(95.6)$ \\
\hline
\end{tabular}

Most of the participants thought that it was somewhat important (51.2\%) or very important (42.9\%) to reduce salt, but less than half (42.2\%) actively try to reduce salt in the diet. Most participants always $(80.2 \%)$ or sometimes $(13 \%)$ add salt while cooking,
Table 3: Binary logistic regression showing the effect of various factors on predicting whether a person will try to reduce their salt intake in a sample from Muscat Governorate, Oman $(\mathrm{N}=1,214)$

$\begin{array}{lccc}\text { Input variable } & \text { SE } & \text { df } & P \text { value } \\ \text { Gender } & 0.133 & 1 & <0.001 \\ \text { Education level } & 0.062 & 1 & <0.001 \\ \text { Occupation } & 0.080 & 1 & 0.018 \\ \text { Hypertension } & 0.199 & 1 & 0.618 \\ \text { Age } & 0.007 & 1 & 0.000 \\ \text { SE = Standard error; } d f=\text { degrees offreedom. } & & \end{array}$

Table 4: Differences between the groups who attempt to reduce and those that do not attempt to reduce dietary salt in a sample from Muscat Governorate, Oman $(\mathrm{N}=1,124)^{*}$

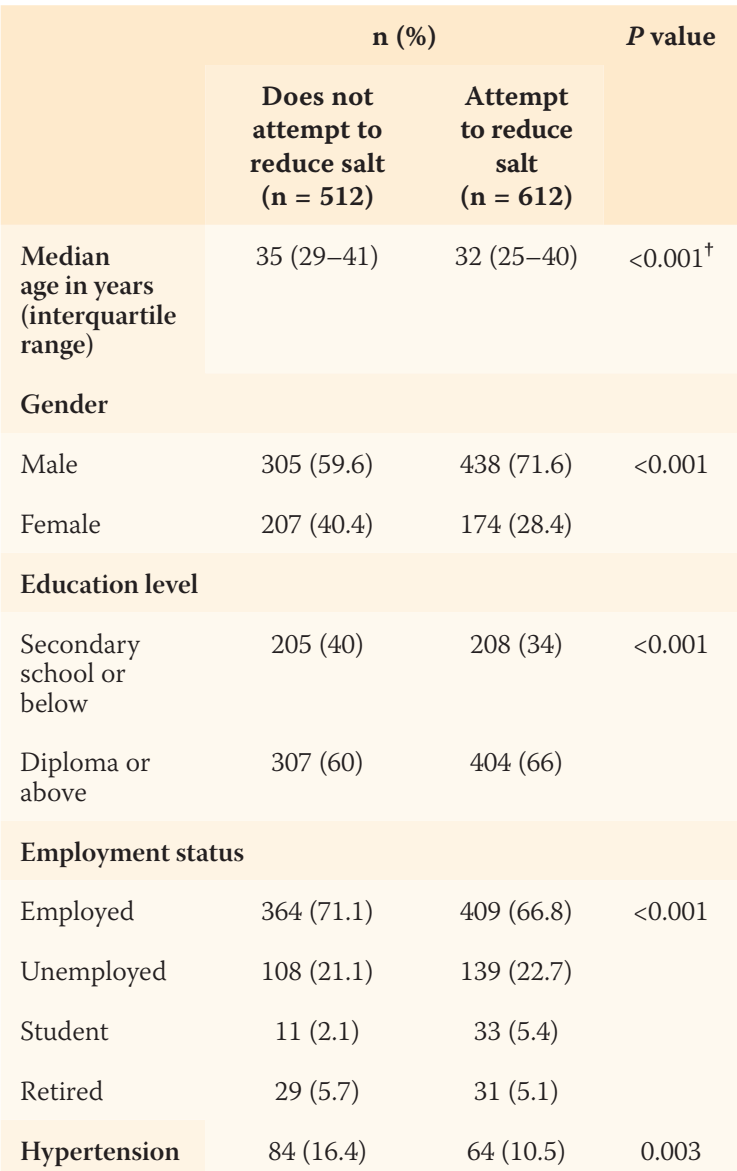

"This analysis excludes 90 respondents who answered "Don't know" to the question "Do you try to reduce salt in your diet"; ${ }^{\dagger}$ Analysis by MannWhitney $U$ test, all other analyses were by Chi-square test.

although only $39.6 \%$ never add salt at the table. Only around a quarter $(26.4 \%)$ check the salt content on the label of food items before purchasing [Table 2].

Almost all (90.9\%) were aware that excess salt is harmful and can cause diseases such as hypertension. However, only few (11.6\%) were aware that other conditions besides hypertension, such as renal stones and osteoporosis, can also be caused by excess dietary 
salt. Most of the participants (69.4\%) felt that they were consuming the right amount of salt and only a few (6.7\%) felt they were consuming more, with the remaining $23 \%$ feeling that they were consuming less. Only 54 participants (4.4\%) claimed they knew what the recommended limit of salt intake was, yet only 12 (1\%) got the value correct.

On binary logistic regression, the factors that determine whether a person tries to reduce dietary salt were age, gender, educational level and occupation (all $P<0.02$ ) [Table 3]. However, being hypertensive was not a predictor. According to the analysis, those who attempted to reduce their dietary salt were younger males with an education status of diploma or above and unemployed (all $P<0.001$ ). Unexpectedly, hypertensive patients were less likely to try and reduce dietary salt as compared to non-hypertensive participants [Table 4]. Known hypertensive participants were not analysed separately as their number was small (14\%).

\section{Discussion}

Salt is an essential dietary component that can be traced back to ancient civilisations where it formed an important part of the economies of these communities. ${ }^{20}$ Besides its use in household kitchens, it is also used extensively in commercially produced processed food, both for preservation and flavour. The dependence of modern fast-paced lifestyles on these readily available high salt-containing "fast foods" has led to a significant increase in our dietary salt intake, which has become a major public health concern. ${ }^{3,8,21}$

Increasing public awareness is an important step in the reduction of salt consumption. Mass media campaigns are a commonly used medium of health education and they play an important part in improving awareness with the expectation that this would lead to healthy behaviour. ${ }^{22,23}$ While these efforts have been shown to be effective in some settings, such as smoking cessation or diabetic control, a recent meta-analysis showed that these measures alone are not sufficient to reduce salt intake and the levels of salt consumption remains consistently high. ${ }^{24,25,26,27}$

However, raising awareness is indeed the first step in modifying behaviour. In the current study, the efforts of mass media campaigns appear to be successful, as the majority of respondents were aware that high salt intake is dangerous. However, this knowledge does not appear to be actually applied as only less than half the participants admitted to actively trying to reduce their salt intake.

Part of the reason for this awareness-behaviour mismatch, could be due to misconceptions about how much salt is considered safe. It is discouraging to know that most of the respondents did not know the recommended level, yet were content with their salt intake and claimed that they were consuming the correct amount despite previous studies proving the contrary. ${ }^{15}$

These findings are similar to those reported from other countries, where individuals felt they were consuming salt within the recommended levels, whilst unaware of the correct levels. ${ }^{28}$ Health education programmes in Oman should increase public awareness of the high salt-containing foods that are regularly consumed in their modern diets and emphasise the need for everyone to actively reduce their salt intake by checking the labels on food items before purchasing, using low salt alternatives and consuming less processed foods.

Besides public education, it is necessary to actively reduce salt in commonly consumed commercially produced food products, since current lifestyles rely heavily on them. One example in Oman, in conjunction with government policies, local bakeries produced bread with lower salt content than those from other countries. ${ }^{29}$ Labelling should also be clear in high salt-containing food items, as is being done in some countries to help consumers make low salt choices. ${ }^{30}$

The current survey was limited to Muscat Governorate, which is urban, and did not take into consideration the vast geographical extent of Oman. Dietary practices in urban Muscat could be different from those in the rural parts of Oman. Most of the respondents were educated and were either students or in full-time employment, which does not truly represent the demographics of Oman. ${ }^{31}$ As this was a questionnaire-based study, there was inherent respondent bias which could be a limitation of such a study. ${ }^{32}$ In the current study, the actual salt consumption in the population studied was not evaluated, as there is still controversy regarding the optimal method of estimation of salt consumption. ${ }^{33}$ Therefore, the results relied on the respondents opinion of their own salt consumption. Further follow-up studies involving measurement of the salt intake among the Omani population are warranted, as the latest existing data are from $2004 . .^{15}$

However, the strength of the current study is in the large sample size $(\mathrm{N}=1,214$; standard error $<3 \%)$, which is sufficient to draw conclusions with regards to knowledge and attitudes towards salt intake, at least for the urban population in Muscat Governorate, Oman. 


\section{Conclusion}

General awareness regarding the dangers of high salt intake among the urban population sample of Muscat Governorate was high. However, the participants' knowledge did not match their practices, as most were not actively trying to reduce their dietary salt intake. More public awareness campaigns are required to help people reduce their salt intake.

\section{Reference}

1. Roth GA, Johnson C, Abajobir A, Abd-Allah F, Abera SF, Abyu G, et al. Global, Regional, and National Burden of Cardiovascular Diseases for 10 Causes, 1990 to 2015. J Am Coll Cardiol 2017; 70:1-25. https://doi.org/10.1016/j.jacc.2017.04.052

2. Bromfield S, Muntner P. High blood pressure: the leading global burden of disease risk factor and the need for worldwide prevention programs. Curr Hypertens Rep 2013; 15:134-6. https://doi.org/10.1007/s11906-013-0340-9.

3. Aaron KJ, Sanders PW. Role of dietary salt and potassium intake in cardiovascular health and disease: a review of the evidence. Mayo Clin Proc 2013; 88:987-95. https://doi.org/10.1016/j. mayocp.2013.06.005.

4. Antonios TF, MacGregor GA. Salt intake: Potential deleterious effects excluding blood pressure. I Hum Hypertens 1995; 9:511-5

5. D'Elia L, Rossi G, Ippolito R, Cappuccio FP, Strazzullo P. Habitual salt intake and risk of gastric cancer: a meta-analysis of prospective studies. Clin Nutr 2012; 31:489-98. https://doi. org/10.1016/j.clnu.2012.01.003.

6. Edwards DG, Farquhar WB. Vascular effects of dietary salt. Curr Opin Nephrol Hypertens 2015; 24:8-13. https://doi. org/10.1097/MNH.0000000000000089.

7. Rohrmann S, Linseisen J. Processed meat: The real villain? Proc Nutr Soc 2016; 75:233-41. https://doi.org/10.1017/ S0029665115004255

8. World Health Organisation Fact sheet; Salt reduction. 2018. http://www.who.int/news-room/fact-sheets/detail/saltreduction Accessed: Apr 2020.

9. Powles J, Fahimi S, Micha R, Khatibzadeh S, Shi P, Ezzati M, et al. Global, regional and national sodium intakes in 1990 and 2010: A systematic analysis of 24 h urinary sodium excretion and dietary surveys worldwide. BMJ Open 2013; 3:e003733. https://doi.org/10.1136/bmjopen-2013-003733.

10. Farrand C, He FJ, MacGregor GA. Reducing population salt intake in the Eastern Mediterranean Region - time for urgent action. East Mediterr Health J 2015; 20:761-4. https://doi. org/10.26719/2014.20.12.761.

11. He FJ, MacGregor GA. A comprehensive review on salt and health and current experience of worldwide salt reduction programmes. J Hum Hypertens 2009; 23:363-84. https://doi. org/10.1038/jhh.2008.144.

12. MacGregor GA, He FJ. World Action on Salt. Lancet 2008; 371:471. https://doi.org/10.1016/S0140-6736(08)60228-7.

13. World Health Organisation. Global status report on non communicable diseases. 2020. http://www.who.int/nmh/ publications/ncd_report_full_en.pdf Accessed: Apr 2020.

14. The impact of chronic diseases in Oman. 2015. https://www. who.int/chp/chronic disease_report/media/impact/oman. pdf?ua=1 Accessed: Apr 2020.

15. Oman food fortification study. 2004. http://ghdx.healthdata. org/record/oman-food-fortification-study-2004 Accessed: Apr 2020.
16. Alhamad N, Almalt E, Alamir N, Subhakaran M. An overview of salt intake reduction efforts in the Gulf Cooperation Council countries. Cardiovasc Diagn Ther 2015; 5:172-7. https://doi. org/10.3978/j.issn.2223-3652.2015.04.06.

17. Salt reduction in bread in Oman. 2020. https://www.who.int/ beat-ncds/countries/oman/salt-reduction/en/ Accessed: Apr 2020.

18. WHO attitudes and behaviour towards salt intake. 2018. http:// www.who.int/ncds/surveillance/steps/riskfactor/STEPS_ SaltModule.pdf Accessed: Apr 2020.

19. Sample size calculations for questionairre based studies. 2015. https://issuu.com/medecinsdumonde/docs/47-the-kapsurvey-model-knowledge-a/9 Accessed: Apr 2020.

20. Cirillo M, Capasso G, Di Leo VA, De Santo NG. A history of salt. Am J Nephrol 1994; 14:426-31.

21. U.S. Department of Health and Human Services, U.S. Department of Agriculture. What We Eat in America. 2018. https://www.ars.usda.gov/ARSUserFiles/80400530/pdf/1314/ Table_1_NIN_GEN_13.pdf Accessed: Apr 2020.

22. Randolph W, Viswanath K. Lessons learned from public health mass media campaigns: marketing health in a crowded media world. Annu Rev Public Health 2004; 25:419-37. https://doi. org/10.1146/annurev.publhealth.25.101802.123046.

23. Wakefield MA, Loken B, Hornik RC. Use of mass media campaigns to change health behaviour. Lancet 2010; 376:1261-71. https://doi.org/10.1016/S0140-6736(10)60809-4.

24. Naugle DA, Hornik RC. Systematic review of the effectiveness of mass media interventions for child survival in low- and middle-income countries. J Health Commun $2014 ; 19: 190-215$. https://doi.org/10.1080/10810730.2014.918217.

25. Sugden C, Phongsavan P, Gloede S, Filiai S, Tongamana VO. Developing antitobacco mass media campaign messages in a low-resource setting: Experience from the Kingdom of Tonga. Tob Control 2017; 26:344-8. https://doi.org/10.1136/ tobaccocontrol-2015-052755

26. Trieu K, McMahon E, Santos JA, Bauman A, Jolly KA, Bolam B, et al. Review of behaviour change interventions to reduce population salt intake. Int J Behav Nutr Phys Act 2017; 14:17. https://doi.org/10.1186/s12966-017-0467-1.

27. Brown IJ, Tzoulaki I, Candeias V, Elliott P. Salt intakes around the world: implications for public health. Int J Epidemiol 2009; 38:791-813. https://doi.org/10.1093/ije/dyp139.

28. Bhattacharya S, Thakur JS, Singh A. Knowledge attitude, and practice regarding dietary salt intake among urban slum population of North India. J Family Med Prim Care 2018; 7:526-30. https://doi.org/10.1093/ije/dyp139.

29. Abukhader M, Abdelraziq R, Alazawi M, Ali S. A comparative examination of dietary sodium content in bread and its public consumption pattern in Muscat, Oman. Nutr Food Sci 2019; 50:116-30.

30. Pietinen P, Valsta LM, Hirvonen T, Sinkko H. Labelling the salt content in foods: a useful tool in reducing sodium intake in Finland. Public Health Nutr 2008; 11:335-40. https://doi. org/10.1017/S1368980007000249.

31. Demographics in Oman. 2020. https://www.ncsi.gov.om/ Pages/NCSI.aspx Accessed: Apr 2020.

32. Safdar N, Abbo LM, Knobloch MJ, Seo SK. Research Methods in Healthcare Epidemiology: Survey and Qualitative Research. Infect Control Hosp Epidemiol 2016; 37:1272-7. https:/doi. org/10.1017/ice.2016.171

33. McLean RM. Measuring population sodium intake: A review of methods. Nutrients 2014; 6:4651-62. https://doi.org/10.3390/ nu6114651. 